\title{
Técnica e sensibilidade no ensino médico em tempos de distanciamento social
}

\author{
Technique and sensibility in medical \\ teaching in times of social distance
}

\section{lêda Aleluia' ${ }^{1}$ \\ Maristela Sestelo ${ }^{2}$ (1) \\ Nelma Arônia 3 (1)}

\begin{abstract}
${ }^{1}$ Autora para correspondência. Universidade do Estado da Bahia (Salvador). Bahia, Brasil. iedaleluia@bahiana.edu.br ²Escola Bahiana de Medicina e Saúde Pública e Universidade do Estado da Bahia (Salvador). Bahia, Brasil. maristelasestelo@bahiana.edu.br 3Universidade do Estado da Bahia (Salvador).Bahia, Brasil.nasantos@uneb.br
\end{abstract}

Vivemos em um tempo em que a tecnologia atingiu um alto patamar de importância na vida das pessoas como nunca antes. Um tempo de redes digitais e sociais, de comunicação possível a qualquer momento do dia ou da noite. Tempo de leituras digitais, toques digitais e diagnósticos digitais. Tempo de Inteligência Artificial, de recursos diagnósticos rápidos e precisos. Mas, também, tempo de produção acelerada em todos os campos do saber. Tempo no qual, conversar, contar histórias e ouvi-las parece não fazer muito sentido; parece um tempo passado, imperfeito, antiquado.

Diante desse contexto, vivemos o paradoxo na educação em saúde, mais especificamente, na educação médica. Como conciliar estes dois extremos: da técnica e da sensibilidade; da tecnologia e da subjetividade?

Pensando nisso, e amparadas nos estudos feitos sobre a interação entre a literatura e a medicina ${ }^{1}$, bem como na íntima convicção de cada uma de nós três (02 professoras de Semiologia e 01 de Literatura Contemporânea; professoras de Medicina e de Letras), resolvemos aproveitar o espaço oferecido para o ensino, na forma virtual, de algo que fosse significativo para o campo da saúde, especialmente, durante a pandemia de Covid-19. Um espaço virtual no qual conexões e reflexões pudessem ser estabelecidas entre campos de saberes aparentemente tão diferentes: a Medicina e a Literatura.

E foi nesse contexto, proporcionado por um organismo acelular, aos olhos, que colocou todas as certezas, recursos e produção em slow down; forçou um distanciamento social, restringiu o toque entre as pessoas, surgindo, portanto, a ideia de oferecer o curso de extensão "A Medicina em interface com a Literatura: Sobre o uso da narrativa oral no consultório". Pensado para oferecer um campo para as humanidades em saúde, e a partir desse ponto, criar um espaço de escuta, fala, conhecimento e reconhecimento, em onze encontros.

O resultado desse curso é apresentado aqui, neste número especial da Revista Internacional de Educação e Saúde (RIES): oito ensaios produzidos pelos participantes, estudantes de medicina e de letras. Oito textos que falam de vida, força, subjetividade e alma. Oito textos feitos a várias mãos, com várias experiências e muitas reflexões. 
Os artigos foram produzidos com base nos temas abordados no curso: exercício de escuta e escrita; a doença como metáfora; o paciente no consultório; o paciente no hospital; a descrição e narrativa do óbito; médico como paciente; bastidores da anatomia e despersonalização do paciente e de sua história.

Queremos apresentar esse encontro aqui, e que os leitores se encontrem também com os fios que teceram e conduziram o grupo a esse resultado. Que vejam a arte como uma poderosa estratégia de ensino, na qual subjetividade e ciência não se excluem, mas acham um caminho comum e reitera, como diria Mia Couto², "nós somos feitos de histórias, tal qual somos feitos de células, e precisamos resgatar nossa propensão genética à imaginação narrativa."

\section{Referências}

1. Taylor A, Lehmann S, Chisolm M. Integrating humanities curricula in medical education: a literature review. MedEdPublish. 2017;6(2):28. https://doi.org/10.15694/mep.2017.000090.2

2. Vargas T. "'Somos feitos de histórias, assim como somos feitos de células" [Internet]. Ministério da Saúde; 2015 [citado em 2020 out. 05]. Disponível em: http://www.ensp.fiocruz.br/portal-ensp/ informe/site/materia/detalhe/38630 